\title{
Typology of Adolescents in Terms of Risk Behavior - Differentiation in Terms of Parental Conditions
}

DOI: 10.15804/tner.2021.63.1.06

\begin{abstract}
The aim of the study is to identify the typology of adolescents in terms of manifestations of risk behavior and to find out the differences between them from the perspective of parental conditions. The research tools are the E.M.B.U Questionnaire - My memories of upbringing, ECR - Experience in Close Relationship, the author's questionnaire aimed at identifying substance use and selected items of the Questionnaire on belonging to a Delinquent Group. The research sample consisted of 850 adolescents. Cluster analysis identified three types of adolescents in terms of manifestations of risk behavior. Differentiations between groups in the parental conditions were identified.
\end{abstract}

Key words: risk behavior, adolescence, emotional attachment, parental behavior styles, cluster analysis

\section{Introduction}

Adolescence is a very vulnerable period in relation to the development of various forms of risk behavior due to many changes in the life of young people. This behavior is characterized by a negative divergence from the generally accepted norms and rules and it leads to increased health, social and other risks for individuals and society at large. The various manifestations of risk behavior usually do not occur in isolation but rather in combination. Following Jessor's 
(1991) risk behavior theory, it is a combination of alcohol consumption, cigarette smoking, marijuana use, delinquent behavior, and an early initiation to sexual life. According to Jessor, these manifestations are represented by the problem/ risk behavior syndrome in adolescence: RBS-A (risk-behavior syndrome - RBS, problem behavior syndrome - PBS). The theoretical support for the problem behavior syndrome is based on the results of two longitudinal studies, which have repeatedly identified both the positive interrelations of the above forms of problem behavior and the negative interrelations of these manifestations with conformist behavior.

The theory assumes that risk behavior results from the person's interaction with the environment in which he/she lives. Based on this premise, the factors involved in the genesis of risk behavior can be divided into 5 systems:

- biological system

- social environment

- perceived environmental system

- personality system

- behavioral system

The biological factors include inherited variables such as gender, physique and intellectual prerequisites. Stable socio-demographic characteristics (e.g. education, profession, religion, income) or social context (e.g. family environment, school, location) affect the development of risk behavior through how individuals perceive and evaluate them and what attitude they develop to them. According to Jessor, the subjective perception and evaluation of the social environment - particularly the perception and evaluation of relations with other people (especially parents and peers) - has the strongest impact on the development of risk behavior.

In the present text, we focus on the analysis of social context, especially parenting and emotional attachment, in the context of adolescent risk behavior. Family plays a key role in how an individual develops his/her skills in dealing and coping with difficult life situations. Through their experience with relational persons, individuals learn how to manage negative emotions and anxiety when facing a stressful or dangerous situation. This learning is mediated by their ability to emotionally self-regulate, i.e. by the ability to recognize these emotions, and how and when these emotions are expressed and lived out. Emotional self-regulation results from the availability and responses of the relational person. The experience resulting from these ties has an impact on the development of relationships with peers, emotional skills and other components of mental health in adolescence. The low level of emotional self-regulation is a factor that increases the likelihood of risk behavior in children and adolescents (Estévez et al., 2017). 
Often, the typical pubertal craziness is only attributed to hormones. However, recent brain research shows that there is still an intensive phase of brain development during puberty that helps bring about the familiar behaviors (e.g., risky behavior). This brain development takes place in both the remodeling of structures and the internal processes. The change begins in the depth of the brain, in the regions that are very important for emotions. Thus, the so-called „reward system” is massively changed: There is a decrease in the density of receptors for dopamine (up to 30\% loss) and serotonin. As a result, fewer stimuli reach the frontal area of the brain and also the mesolimbic system (part of the reward system). This reduces the perception of reward despite external stimuli remaining the same. A reduction in the size of a very important part of the reward system, the nucleus accumbens, is accompanied by an increase in anhedonia (Auerbach et al., 2017). Together with the weakening of the reward network and thus the subjective experience of fun, at the beginning of puberty the individual's own mood often dims, sometimes even to the point of depressive moods. This commonly leads to a loss of motivation at school (Krick, 2016, p. 25). Because of this lack of stimuli, adolescents experience boredom and disinterest in their previous activities and, with the involvement of a central part of emotion regulation, the amygdala, they search for new stimuli in often too "high a dosage”. This then leads to dangerous risk behaviors of all kinds. The reward system is now also more receptive to chemical „happy makers”. However, these exacerbate receptor degradation. In risk behaviors and addictions, impulsivity and lack of control play an important role. Areas of the frontal brain are essentially responsible for this control. And here is the second area of change noted in puberty: Throughout the cerebrum, there is an increase in white matter (the nerve cables) due to myelination (the sheathing of fibers) and a decrease in gray matter (the cells and junctions, the synapses) (Blakemore \& Frith, 2006, pp. 167-168; Juraska \& Willing, 2017; Mills et al., 2016; Piekarski et al., 2017; Truelove-Hill et al., 2020; Zhou et al., 2015). The decrease in gray matter also conditions the decrease in cortical thickness (Gennatas et al., 2017; Tamnes et al., 2017, p. 3402; Zhou et al., 2015, p. 140). These biological changes, especially in the frontal brain, are necessary for better efficiency of cognitive processes, but have the temporary disadvantage of poorer control of emotional behaviors. Only the maturation of the connections between the subcortical (e.g., the reward system) with the cortical networks (e.g., the frontal brain) brings greater rationality (Baker et al., 2015; Duijvenvoorde et al., 2016; Sato et al., 2015). But of course, this also needs time for development and certainly also encouraging influences from the environment (Foulkes \& Blakemore, 2018). Puberty and adolescence are important, but unfortunately also dangerous phases: For example, increased anxiety disorders 
and depression begin during puberty (Sato et al., 2015, p. 49; Young et al., 2019): interactions between social changes and brain biological processes are probably responsible for „disrupted emotional regulation.” But „antecedents” probably also play a role: genetic and epigenetic underpinnings, early developmental events, and, of course, social conditions, especially clique (Sherman et al., 2019; Steinberg cited in Ayan, 2010, p. 17), but significantly family factors. It is hoped that this study will contribute to clarifying the contribution of family conditions:

The style of parenting and attachment is associated with risk behavior, including substance abuse. Several research studies suggest that particularly the rejection and lower emotional warmth of parents is associated with substance abuse and non-substance addictions (Emmelkamp \& Heeres, 1988; Andersson \& Eisemann, 2003; Glavak, 2006; Rai, 2008, Savrnochova et al., 2020). Ruchkin et al. $(1998,2002)$ found that delinquent youth with a positive history of alcohol addiction assesses parental behavior as rather rejecting and less emotionally warm in the anamnesis compared to the adolescents who showed no history of addiction. Rejection in particular appears to be a significant factor in relation to substance use (e.g. Pant \& Priyanka, 2006) even in relation to risk behavior, delinquency and aggression. Kassel et al. (2007) found that anxiety attachment (fear of abandonment) is the most important predictor of substance abuse.

Fairbairn et al. (2018) conducted a meta-analysis in order to identify the link between attachment and substance abuse. The authors identified a small but significant link between attachment and substance abuse, noting that individuals with insecure bonds use addictive substances at a higher rate compared to those with secure bonds. They also found that the correlation between attachment and addictive substance use persists in time, and the insecure attachment bonds predate the subsequent substance use.

\section{Research Focus}

Based on the results of relevant research studies, we noted a correlation between parenting styles, emotional attachment and manifestations of risk behavior in adolescence. The aim of the present study is to identify the typology of adolescents for signs of risk behavior and identify the differences between the identified types in terms of parental style of behavior and emotional attachment. In view of the main aim, the following partial objectives can be formulated:

RQ1: What is the typology of adolescents in terms of risk behavior and its manifestations?

RQ2: Are there significant differences in the parental upbringing styles and emotional attachment between the identified groups of adolescents? 
RQ3: What type of relational bonds prevail in the identified groups of adolescents?

\section{Methodology of Research}

\section{Sample of Research}

The sample consisted of 850 secondary school students in Ružomberok. The sample included 509 (59.9 \%) girls and 341 (40.1\%) boys. The mean age was 17.04 years (SD 1.063). Altogether $72 \%$ of respondents lived in a complete family, $27.6 \%$ in an incomplete family, and 3 respondents did not answer the question. Catholic religion (77.8\%) dominated in the sample, followed by atheists $(13.5 \%)$ and Lutheran religion (5.9\%). 17 respondents indicated the „other” option, and 7 respondents did not provide an answer.

The administration of questionnaires and data collection was conducted through drug prevention coordinators at the relevant secondary schools. The drug prevention coordinators were instructed on how the students should fill in the submitted questionnaires. For this purpose, each school has reserved one lesson.

\section{Instrument and Procedures}

The E.M.B.U Questionnaire - My Memories of Upbringing is a 23-question self-assessment questionnaire aimed at assessing how individuals remember the parental behavior of their parents. It consists of three separate factors (subscales):

- rejection - consisting of 7 questions including punishment, underestimation, shaming, giving preference to other siblings and not the respondent, rejection through criticism, lack of tenderness, rejection of the respondent as an individual, and insults (e.g. ,It just so happened that my parents were annoyed or angry without telling me why.");

- emotional warmth - consisting of 6 questions including praise, motivation, tenderness, adequate interest, creation of a stimulating educational environment, warmth, tenderness and pride (e.g. „I felt that my parents were proud of me.");

- overprotection - consisting of 10 questions including fears and anxiety about the respondent's security, intrusiveness, hyper-involvement (e.g. „I had a feeling that my parents interfered with everything I did.") (Arrindell et al., 1991).

The internal consistency of the above factors in our study was as follows: rejection $\alpha=0.781$ (mother), $\alpha=0.789$ (father); emotional warmth $\alpha=0.806$ (mother), $\alpha=0.825$ (father); overprotection $\alpha=0.773$ (mother), $\alpha=0.751$ (father). 
The ECR-R - Experience in Close Relationship-Revised is a 36-question self-assessment instrument to measure two dimensions of emotional attachment:

- anxiety - reflects the anxiety and alertness regarding rejection and abandonment (e.g. „When I manifest my feelings toward a parent, I am afraid he/she will not feel the same to me");

- avoidance - corresponds to the discomfort in relation to closeness and dependence on others (e.g. „I do not feel good when I have to confide in my parents."). This questionnaire was made by Brennan et al. (1998).

The internal consistency of factors in our study was as follows: $\alpha=0.928$ anxiety and $\alpha=0.924$ avoidance.

The substance abuse questionnaire designed by us focused on investigating the frequency of substance use: cigarettes, alcohol, marijuana. We used an 8-point scale $(7=$ daily, $0=$ never $)$.

Further, we surveyed the age of first sexual intercourse and the respondents' involvement in delinquent groups, which was identified with the questions from the Delinquent Group Questionnaire published by Moravcová (2012) - for example. “Are some illegal things tolerable in your group?” „Are people in your group involved in some sort of unlawful or illegal activity?"

\section{Data Analysis}

The data were analyzed in IBM SPSS ${ }^{\circledast}$ (version 22 ) by means of inductive statistics (ANOVA, Tukey post-hoc test, chi-square). We used cluster analysis to identify the typology of respondents in terms of the manifestations of risk behavior.

\section{Results of Research}

\section{RQ1: What is the typology of adolescents in terms of risk behavior and its manifestations?}

We have carried out cluster analysis to identify the subtypes of risk behavior. We adjusted the search criteria for an optimal number of clusters to a maximum value of 10 using the Schwarz Bayesian information criterion (SBIC). Using the above procedure, the system identified 3 clusters as an appropriate number, and these clusters are listed in Tab. 1. 
Table 1. Clusters of respondents according to the manifestations of risk behavior

Clusters

Input (Predictor) Importance

$1,0 \square 0,8 \square 0,6 \square 0,4 \square 0,2 \square 0,0$

\begin{tabular}{|c|c|c|c|}
\hline Cluster & 2 & 1 & 3 \\
\hline Label & EXPERIMENTERS & RISK & RISK-FREE \\
\hline Description & $\begin{array}{c}\text { delinquency: NO, } \\
\text { addictive substances: } \\
\text { YES - experimentally, } \\
\text { sex: } 62 \% \text { YES }\end{array}$ & $\begin{array}{l}\text { delinquency: YES, } \\
\text { addictive substances: } \\
\text { YES - most often, sex: } \\
69 \% \text { YES }\end{array}$ & $\begin{array}{c}\text { delinquency: NO, } \\
\text { addictive substances } \\
\text { cigarettes/marijuana } \\
\text { NO, alcohol - } \\
\text { occasionally, sex: NO }\end{array}$ \\
\hline Size & $\begin{array}{r}47,5 \% \\
(322)\end{array}$ & $\begin{array}{r}27,6 \% \\
(187)\end{array}$ & $\begin{array}{r}24,9 \% \\
(169)\end{array}$ \\
\hline \multirow[t]{6}{*}{ Inputs } & $\begin{array}{c}\text { Are people in your } \\
\text { group involved in } \\
\text { some sort of unlawful } \\
\text { or illegal activity? } \\
\text { no }(82.6 \%)\end{array}$ & $\begin{array}{l}\text { Are people in your } \\
\text { group involved in } \\
\text { some sort of unlawful } \\
\text { or illegal activity? } \\
\text { ves }(97.99 \%)\end{array}$ & $\begin{array}{c}\text { Are people in your } \\
\text { group involved in } \\
\text { some sort of unlawful } \\
\text { or illegal activity? } \\
\text { no }(100.0 \%)\end{array}$ \\
\hline & $\begin{array}{c}\text { Are some illegal } \\
\text { things tolerable in } \\
\text { your group? } \\
\text { no }(76,1 \%)\end{array}$ & $\begin{array}{c}\text { Are some illegal } \\
\text { things tolerable in } \\
\text { your group? } \\
\text { yes }(85,6 \%)\end{array}$ & $\begin{array}{c}\text { Are some illegal } \\
\text { things tolerable in } \\
\text { your group? } \\
\text { no }(100,0 \%)\end{array}$ \\
\hline & $\begin{array}{c}\text { cigarettes } \\
\text { never }(43,5 \%)\end{array}$ & $\begin{array}{c}\text { cigarettes } \\
\text { every day }(49,2 \%)\end{array}$ & $\begin{array}{c}\text { cigarettes } \\
\text { never }(98,8 \%)\end{array}$ \\
\hline & $\begin{array}{c}\text { marijuana } \\
\text { never }(83,5 \%)\end{array}$ & $\begin{array}{c}\text { marijuana } \\
\text { never }(31,0 \%)\end{array}$ & $\begin{array}{c}\text { marijuana } \\
\text { never }(100,0 \%)\end{array}$ \\
\hline & $\begin{array}{c}\text { sexual intercourse } \\
\text { yes }(62,1 \%)\end{array}$ & $\begin{array}{c}\text { sexual intercourse } \\
\text { yes }(69,0 \%)\end{array}$ & $\begin{array}{c}\text { sexual intercourse } \\
\text { no }(100,0 \%)\end{array}$ \\
\hline & $\begin{array}{l}\text { alcohol } \\
\text { half-yearly }(19,9 \%)\end{array}$ & $\begin{array}{c}\text { alcohol } \\
\text { once a week }(34,2 \%)\end{array}$ & $\begin{array}{c}\text { alcohol } \\
\text { never }(45,0 \%)\end{array}$ \\
\hline
\end{tabular}

The typical feature of the first group, which we call "risk", is that almost all its members (98\%) practice some form of illegal activities, and for $86 \%$ of them such behavior is acceptable/normal. Up to $49 \%$ of respondents smoke cigarettes every day, only $31 \%$ of them never tried marijuana $(26.2 \%$ of respondents use it semi-annually, $12.8 \%$ of respondents once a month, $10 \%$ more than once a month, and $11 \%$ several times a week or every day), and alcohol is most frequently consumed once a week by $34.2 \%$ of respondents ( $15.5 \%$ once every two weeks and $11 \%$ several times a week). Up to $69 \%$ of respondents have already had sex (at a mean age of 15.43, SD 1.24). 
Most respondents in the second group, which we call „experimenters”, are not involved in illegal activities (83\%) and they do not consider them to be acceptable/ normal (76\%). With regard to substance abuse, we conclude that:

- cigarettes are not used by $43.5 \%$ of respondents in this group, $24 \%$ smoke every day, $13 \%$ on a half-yearly basis, and other data arrays were only represented marginally (below 5\%);

- marijuana was never consumed by $83.5 \%$ of respondents, $11.2 \%$ reported a semi-annual rate, and $3.4 \%$ use it once a month. Other data arrays were only represented marginally (below $1 \%$ );

- alcohol is mostly consumed on a half-yearly basis (19.9\%), followed by monthly consumption by $18.9 \%$ of respondents, it is never consumed by $16.1 \%$, several times a month by $16.1 \%$, once every two weeks by $10.2 \%$ and once a week by $11.8 \%$ of respondents;

- Up to $62.1 \%$ of respondents have already had sex (at a mean age of 16.01, SD 1.28).

The third group, which we call "risk-free”, is characterized by the absence of illegal activities, which are considered unacceptable or abnormal (100\%). Almost all respondents in this group never smoked cigarettes $(98.8 \%)$ and marijuana (100\%). Up to $45 \%$ of respondents never tried alcohol (20.7\% semi-annually, $16 \%$ once a month). The respondents in this group have not had sexual intercourse (100\%) before.

We have also analyzed the differences among the demographic characteristics in the identified groups. We can establish the existence of a slightly higher representation of females $(\chi 2(2)=6.452, p=0.040)$, younger respondents $(F(2)=$ 9.795, $\mathrm{p}=0.000)$, respondents from complete families $(\chi 2(2)=6.890, \mathrm{p}=0.032)$ and Catholics $(\chi 2(3)=19.818, \mathrm{p}=0.003)$ in the risk-free group.

\section{RQ2: Are there any significant differences in the parental upbringing styles and emotional attachment between the identified groups of adolescents?}

The above groups were compared in terms of the relational bond and memorized parental behavior - see Tab. 2 . We conclude that there is a statistically significant difference in the anxiety and avoidance relational bond between the risk and risk-free respondents, with the risk respondents having a higher average score in these variables (mild to medium difference effect).

Similarly, the risk respondents felt a greater degree of rejection from parents compared to the risk-free respondents (medium difference effect). We have not noted any significant differences in the emotional warmth and overprotection 
category although the average points to lower scores in emotional warmth and higher scores in overprotection in the risk respondents compared to the risk-free respondents.

Table 2. Relational bond and memorized parental behavior between the individual types of respondents in terms of risk behavior

\begin{tabular}{|c|c|c|c|c|c|c|c|c|c|c|c|}
\hline & & \multirow[t]{2}{*}{$\mathbf{N}$} & \multirow[t]{2}{*}{$\mathrm{AM}$} & \multirow[t]{2}{*}{ SD } & \multicolumn{2}{|c|}{$\begin{array}{c}95 \% \mathrm{CI} \text { for } \\
\mathrm{AM}\end{array}$} & \multirow[t]{2}{*}{$\mathbf{F}$} & \multirow[t]{2}{*}{ df } & \multirow{2}{*}{$\begin{array}{c}\text { p-hod- } \\
\text { nota }\end{array}$} & \multirow{2}{*}{$\begin{array}{l}\text { Tukey } \\
\text { HSD }\end{array}$} & \multirow{2}{*}{$\begin{array}{l}\text { Co-- } \\
\text { hens'd }\end{array}$} \\
\hline & & & & & Low & Upp & & & & & \\
\hline \multirow[t]{4}{*}{ AVO } & risk & 180 & 2,50 & 1,157 & 2,33 & 2,67 & \multirow[t]{4}{*}{3,051} & \multirow[t]{4}{*}{2} & \multirow[t]{4}{*}{0,048} & \multirow{4}{*}{$\begin{array}{l}\text { risk - } \\
\text { risk- } \\
\text { free } \\
(0,037)\end{array}$} & \\
\hline & $\begin{array}{l}\text { experi- } \\
\text { menters }\end{array}$ & 304 & 2,34 & 1,117 & 2,21 & 2,47 & & & & & 0,232 \\
\hline & risk-free & 166 & 2,20 & 1,126 & 2,03 & 2,37 & & & & & \\
\hline & Total & 650 & 2,35 & 1,134 & 2,26 & 2,44 & & & & & \\
\hline \multirow[t]{4}{*}{ ANX } & risk & 180 & 3,72 & 1,463 & 3,50 & 3,93 & \multirow[t]{4}{*}{3,862} & \multirow[t]{4}{*}{2} & \multirow[t]{4}{*}{0,022} & \multirow{4}{*}{$\begin{array}{l}\text { risk - } \\
\text { risk- } \\
\text { free } \\
(0,007)\end{array}$} & \\
\hline & $\begin{array}{l}\text { experi- } \\
\text { menters }\end{array}$ & 301 & 3,55 & 1,452 & 3,39 & 3,71 & & & & & 0,323 \\
\hline & risk-free & 162 & 3,28 & 1,490 & 3,05 & 3,51 & & & & & \\
\hline & Total & 643 & 3,53 & 1,471 & 3,41 & 3,64 & & & & & \\
\hline \multirow[t]{4}{*}{ RejM } & risk & 185 & 10,79 & 3,026 & 10,35 & 11,23 & \multirow[t]{4}{*}{4,571} & \multirow[t]{4}{*}{2} & \multirow[t]{4}{*}{0,011} & \multirow{4}{*}{$\begin{array}{l}\text { risk - } \\
\text { risk- } \\
\text { free } \\
(0,008)\end{array}$} & \\
\hline & $\begin{array}{l}\text { experi- } \\
\text { menters }\end{array}$ & 312 & 10,41 & 3,240 & 10,05 & 10,77 & & & & & 0,325 \\
\hline & risk-free & 165 & 9,76 & 3,305 & 9,26 & 10,27 & & & & & \\
\hline & Total & 662 & 10,35 & 3,216 & 10,11 & 10,60 & & & & & \\
\hline \multirow[t]{4}{*}{ RejF } & risk & 176 & 10,73 & 3,433 & 10,22 & 11,24 & \multirow[t]{4}{*}{6,035} & \multirow[t]{4}{*}{2} & \multirow[t]{4}{*}{0,003} & \multirow{4}{*}{$\begin{array}{l}\text { risk - } \\
\text { risk- } \\
\text { free } \\
(0,013)\end{array}$} & \\
\hline & $\begin{array}{l}\text { experi- } \\
\text { menters }\end{array}$ & 298 & 10,46 & 3,524 & 10,05 & 10,86 & & & & & 0,380 \\
\hline & risk-free & 156 & 9,51 & 2,965 & 9,04 & 9,98 & & & & & \\
\hline & Total & 630 & 10,30 & 3,395 & 10,03 & 10,57 & & & & & \\
\hline \multirow[t]{4}{*}{ E.wM } & risk & 186 & 16,46 & 3,895 & 15,89 & 17,02 & 1,417 & 2 & 0,243 & & \\
\hline & $\begin{array}{l}\text { experi- } \\
\text { menters }\end{array}$ & 314 & 16,66 & 3,609 & 16,26 & 17,06 & & & & & \\
\hline & risk-free & 166 & 17,12 & 3,988 & 16,51 & 17,73 & & & & & \\
\hline & Total & 666 & 16,72 & 3,789 & 16,43 & 17,01 & & & & & \\
\hline E.wF & risk & 178 & 15,14 & 4,407 & 14,49 & 15,79 & 1,873 & 2 & 0,155 & & \\
\hline & $\begin{array}{l}\text { experi- } \\
\text { menters }\end{array}$ & 300 & 15,64 & 4,092 & 15,17 & 16,10 & & & & & \\
\hline & risk-free & 157 & 16,02 & 4,093 & 15,37 & 16,66 & & & & & \\
\hline & Total & 635 & 15,59 & 4,189 & 15,27 & 15,92 & & & & & \\
\hline
\end{tabular}




\begin{tabular}{|c|c|c|c|c|c|c|c|c|c|c|c|}
\hline & & \multirow[t]{2}{*}{$\mathrm{N}$} & \multirow{2}{*}{$\mathrm{AM}$} & \multirow[t]{2}{*}{ SD } & \multicolumn{2}{|c|}{$\begin{array}{c}95 \% \mathrm{CI} \text { for } \\
\text { AM }\end{array}$} & \multirow[t]{2}{*}{ F } & \multirow[t]{2}{*}{ df } & \multirow{2}{*}{$\begin{array}{l}\text { p-hod- } \\
\text { nota }\end{array}$} & \multirow{2}{*}{$\begin{array}{l}\text { Tukey } \\
\text { HSD }\end{array}$} & \multirow{2}{*}{$\begin{array}{l}\text { Co- } \\
\text { hens'd }\end{array}$} \\
\hline & & & & & Low & Upp & & & & & \\
\hline \multirow[t]{4}{*}{ OverM } & risk & 186 & 22,52 & 5,623 & 21,71 & 23,33 & \multirow[t]{4}{*}{0,566} & \multirow[t]{4}{*}{2} & \multirow[t]{4}{*}{0,568} & & \\
\hline & $\begin{array}{l}\text { experi- } \\
\text { menters }\end{array}$ & 313 & 22,19 & 5,041 & 21,63 & 22,75 & & & & & \\
\hline & risk-free & 167 & 21,93 & 5,284 & 21,12 & 22,74 & & & & & \\
\hline & Total & 666 & 22,22 & 5,266 & 21,82 & 22,62 & & & & & \\
\hline \multirow[t]{4}{*}{ OverF } & risk & 182 & 22,63 & 5,617 & 21,80 & 23,45 & \multirow[t]{4}{*}{0,461} & \multirow[t]{4}{*}{2} & \multirow[t]{4}{*}{0,631} & & \\
\hline & $\begin{array}{l}\text { experi- } \\
\text { menters }\end{array}$ & 306 & 22,22 & 5,061 & 21,65 & 22,79 & & & & & \\
\hline & risk-free & 161 & 22,14 & 5,246 & 21,32 & 22,95 & & & & & \\
\hline & Total & 649 & 22,31 & 5,263 & 21,91 & 22,72 & & & & & \\
\hline
\end{tabular}

Note: 1 AVO - avoidance, ANX - anxiety, Rej - rejection, E.w - emotional warmth, Over - overprotection, $M$ - mother, F-father

$N=$ number,$A M=$ arithmetical mean,$S D=$ standard deviation, $C I=$ Confidence interval, $F-F$-test (ANOVA), $d f$ - degree of freedom, $p$ - level of significance, Tukey HSD - post hoc tests, $d$-Cohen's $d$

\section{RQ3: What type of relational bonds prevail in the identified groups of adolescents?}

The groups of respondents identified in terms of risk behaviors were compared according to the type of emotional bond (secure, dismissing, preoccupied, fearful) incurred as a result of cluster analysis of the anxiety and avoidance factors in the ECR Questionnaire. In the entire research sample, $43 \%$ of respondents had a secure relational bond, and $27 \%$ reported a dismissing, $22 \%$ preoccupied and $6 \%$ fearful relational bond.

When comparing the styles of relational bond between the risk respondents, risk-free respondents and experimenters, we can conclude that $50.1 \%$ of risk-free respondents, $47.7 \%$ of experimenters and $34.5 \%$ of risk respondents reported a secure relational bond. The dismissing style was reported exactly by one third of risk respondents, $30 \%$ of experimenters and $20.5 \%$ of risk-free respondents. The preoccupied style was reported by $26 \%$ of risk respondents and $23 \%$ of experimenters and risk-free respondents. The fearful attachment style was noted in $6.2 \%$ of risk respondents, 5.5\% of experimenters and risk-free respondents - Chart 1 . The differences are statistically significant: $\chi^{2}(6)=7.519, p=0.006$. 


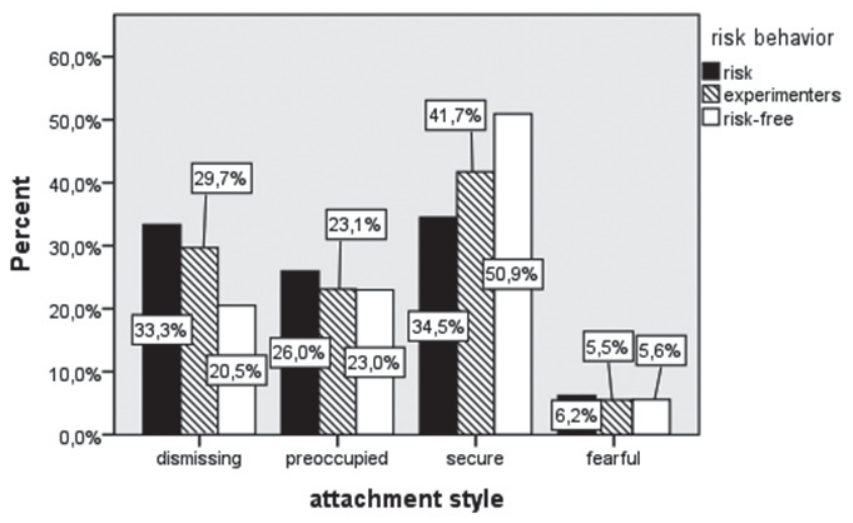

Chart1. Types of respondents according to the signs of risk behavior and type of relational bond

\section{Discussion}

The aim of our study was to identify the typology of adolescents according to the signs of risk behavior and identify the differences between the identified types in terms of parental style of behavior and emotional attachment.

The formation of groups of adolescents in terms of the manifestations of risk behaviors was carried out through cluster analysis, and three groups were identified. The first group consisted of risk respondents (27.6\%), the second of experimenters (47.5\%) and the third of risk-free (24.9\%) adolescents. The highrisk adolescents frequently use addictive substances, most of them had sexual intercourse at an average age of 15.4 years, and they carry out illegal activities. The experimenters were characterized by experimenting with drugs, but less frequently than the risk group. They also differed from the risk group in that they largely refrained from illegal activities. Their first sexual intercourse was at a mean age of 16.01 years, i.e. somewhat later than in the risk group. The last group, i.e. risk-free respondents, differed in that the respondents were not engaged in illegal activities and were not taking addictive substances (cigarettes and marijuana). Although a majority of them had an experience with alcohol, they consumed it significantly less frequently in comparison with the previous groups. The teens in this group have not had sex before. 
The empirically identified types of risk adolescents support Jessor's (1991) theory of linking multiple manifestations of risk behavior. We can conclude that especially the severe and prolonged symptoms of risk behavior are undesirable for individuals and society; therefore, it is important to look for the predictors among the personality traits or characteristics resulting from the early experience with relational persons. For this reason, we identified the groups of adolescents in terms of relational bonds and memorized parental behavior. We found that risk adolescents had a more evasive and anxious relational bond (mild to moderate difference effect) and experienced a higher degree of rejection by the mother and father (mean medium difference effect). In the emotional warmth and overprotection category, the groups of respondents did not differ significantly.

We also investigated the prevailing type of relational bonds in the identified groups in terms of risk behaviors. We found that $50 \%$ of risk-free respondents, $48 \%$ of experimenters and $35 \%$ of risk respondents had a secure relational bond. The anxious-avoidant style was identified in one third of risk respondents, $30 \%$ of experimenters and $21 \%$ of risk-free respondents. The anxious-defying style was noted in $26 \%$ of risk respondents and $23 \%$ of experimenters and risk-free respondents. The fearful attachment style was recorded in $6.2 \%$ of risk respondents and $5.5 \%$ of experimenters and risk-free respondents.

The studied period of adolescence is a developmental milestone in which the individual is looking for a balance between his/her authenticity, a clear place in this world and the desire to become a valid member of society. During this period, individuals are often deliberately taking risks (risk manifestations) when experimenting with social norms and often reinforce their socially dysfunctional forms (Svoboda et al., 2019). Not forgetting the biological factors and also the influence of the clique, we believe that the family environment is an important factor determining the reinforcement of manifestations of risk behavior in adolescents, as can be seen in our research results. This may also be due to the fact that the relationship of parents and children is important because of the children's ability to regulate their behavior, emotional experience and adapt to the existing social norms. If the children have a positive social and emotional experience in relation to their parents, this experience is translated into their other relationships. It is more likely that these children will engage in relationships, in which excessive conformity, violence or expressions of risk and pathological behavior are absent. Conversely, if children do not experience a satisfactory primary relationship, they may exhibit signs of maladaptive behavior and be more susceptible to the risk groups where peer pressure requires them to break the social norms and engage 
in illegal activities. In these groups, they are looking for the alternatives to a secure and warm relationship they did not experience in the primary family.

Overall, the results support the assumption that risk behaviors are associated with a high degree of rejection, lack of emotional warmth from the parents and insecure attachment. This is in line with the findings of Andersson \& Eisemann, 2003; Emmelkamp \& Heeres, 1988; Rai, 2008; Glavak, 2006, Kassel et al., 2007, Fairbairn et al., 2018. Several studies suggest that relational bonds are a phenomenon that affects many areas of human life. Apart from their relation to risk behavior, it has been shown that individuals with insecure attachment use unconstructive ways of coping with problems (escape from or avoidance of problems) (Ognibene \& Collins, 1998; Kelly, 2020), they are less satisfied with life (Ma \& Huebner, 2008; Oral \& Karababa, 2020), and show a greater number of internalizing (anxiety, depression) and externalizing (aggression, hyperactivity) symptoms (Muris et al., 2003; Kanwar, 2020).

\section{Conclusions}

An empirical study of the predictors of risk behavior has a great potential for implementing selective and indicated prevention in the vulnerable period of adolescence. The results of our study show that emotional attachment to parents and the styles of upbringing in the family - particularly the negative ones such as rejection and low emotional warmth from the parents - are an important determinant of risk behaviors in adolescents. The above findings may be useful for the experts dealing with children and young people with risk behaviors (school psychologists, special educators, educators and others) when creating the prevention and intervention strategies.

\section{Pitfalls and limitations of our work}

We are aware that the present work has limitations. These mainly relate to the method of data collection because a questionnaire inherently carries the risk of subjective bias, and is largely dependent on the ability of advanced self-reflection of the respondents. The respondents also might not have fully evaluated their experience with the parental figures from a holistic perspective and their opinion could have been affected by the current experience of their parental figures (e.g. current conflicts, fights, etc.), which might have biased the overall image of the underlying parenting styles and relationships with their parents. 
The above findings and results have become the basic starting point for further investigation. We will use other methods of qualitative strategies to come to a deeper understanding of the analyzed phenomena. The internal working models, relational bonds and some aspects of the relationship with parents may be partly unconscious, and therefore the use of e.g. projective methods might be appropriate in this context.

\section{References}

Andersson, P. \& Eisemann, M. (2003). Parental rearing and individual vulnerability to drug addiction: A controlled study in a Swedish sample. Nordic Journal of Psychiatry, 57(2), s. 147-156.

Arrindell, A.W. et al. (1991). A Parental rearing style questionnaire for use with adolescents: Psychometric evaluation of the EMBU-A. Personality and Individual Differences, 12(12), 1245-1253.

Auerbach, R.P., Pisoni, A., Bondy, E., Kumar, P., Stewart, J.G., Yendiki, A. \& Pizzagalli, D.A. (2017). Neuroanatomical Prediction of Anhedonia in Adolescents. Neuropsychopharmacology, 42, 2087-2095.

Ayan, S. (2010). Der Jugendversteher. Gehirn\&Geist, 3, 14-17.

Baker, S.T.E., Lubman,D.I., Yücel, M., Allen, N.B., Whittle, S., Fulcher, B.D., Zalesky, A. \& Alex Fornito, A. (2015). Changes in Brain Network Hub Connectivity in Late Adolescence. Journal of Neuroscience, 35(24). 9078-9087.

Blakemore, S.-J. \& Frith, U. (2006). Wie wir lernen. Was die Hirnforschung darüber weiß. München: Deutsche Verlags-Anstalt.

Brennan, K., Clark, C., Shaver, P. (1998). Self-report measures of adult romantic attachment. In J. Simpson and W. Rholes, Attachment Theory and Close Relationships. New York: Guilford Press.

Duijvenvoorde van, A.C.K., Achterberg, M., Braams, B.R., Peters, S. \& Crone, E.A. (2016). Testing a dual-systems model of adolescent brain development using resting-state connectivity analyses. NeuroImage, 124(Part A), 409-420.

Emmelkamp, P.M. \& Heeres, H. (1988). Drug Addiction and Parental Rearing Style: A Controlled Study. International Journal of the Addictions, 23(2), 207-216.

Estévez, A. et al. (2017). Attachment and emotion regulation in substance addictions and behavioral addictions. Journal of Behavioral Addictions, 6(4), 534-544.

Fairbairn, C.E. et al. (2018). A Meta-Analysis of Longitudinal Associations between Substance Use and Interpersonal Attachment Security. Psychol Bull, 144(5), 532-555.

Foulkes, L. \& Blakemore, S.-J. (2018). Studying individual differences in human adolescent brain development. Nature Neuroscience, 21, 315-323.

Gennatas, E.D., Avants, B.B., Wolf, D.H., Satterthwaite, T.D., Ruparel, K., Ciric, R., Hakonarson, H., Gur, R.E. \& Gur, R.C. (2017). Age-Related Effects and Sex Differences in 
Gray Matter Density, Volume, Mass, and Cortical Thickness from Childhood to Young Adulthood. Journal of Neuroscience, 37(20) 5065-5073.

Glavak, R. (2006). How heroin addicts perceive their parents ' rearing behaviour: The results of two studies. $1^{\text {st }}$ International Congress on Interpersonal Acceptance and Rejection. Istanbul.

Jessor, R. (1991). Risk Behavior in Adolescence: A psychosocial Framefork for Understanding and Action. Journal of Adolescent Health, 12, 597-605.

Juraska, J.M. \& Willing, J. (2017). Pubertal onset as a critical transition for neural development and cognition. Brain Research, 1654(B), 87-94.

Kanwar, P. (2020). Pubertal timing and externalizing problem behaviours in adolescents: The influence of perceived parental attachments. European Journal of Developmental Psychology, 1-10.

Kassel, J.D., Wardle, M. \& Roberts, J. (2007). Adult attachment security and college student substance use. Addictive Behaviors, 32(6), 1164-1176.

Kelly, C. (2020). Emotional Intelligence, Coping Strategies, and Attachment Style in College Students. (cit. 2020-12-15). Senior Scholars Day. 15. Dostupné na internete: https:// scholarlycommons.susqu.edu/ssd/2020/posters/15/.

Krick, C.M. (2016). Ergebnisbericht zur Studie „Motivierte Schule“. Saarbrücken: Universitätsklinikum des Saarlandes.

Ma, C.Q. \& Huebner, E.S. (2008). Attachment relationships and adolescents' life satisfaction: Some relationships matter more to girls than boys. Psychology in the Schools, 45(2), 177-190.

Mills, K.L., Goddings, A-L., Herting, M.M., Meuwese, R., Blakemore, S.-J., Crone, E.A., Dahl, R.E., Güroğlu, B., Raznahan, A., Sowell, E.R. \& Tamnes, C.K. (2016). Structural brain development between childhood and adulthood: Convergence across four longitudinal samples. NeuroImage, 141, 273-281.

Moravcová, E. (2012). Methodological Aspects of Gang Membership: the Case of the Czech Republic. Acta Universitatis Carolinae Philosophica et Historica. XVIII (2), 69-83.

Muris, P., Meesters, C., Van Den Berg, S. (2003). Internalizing and Externalizing Problems as Correlates of Self-Reported Attachment Style and Perceived Parental Rearing in Normal Adolescents. Journal of Child and Family Studies, 12, 171-183.

Ognibene, T.C. \& Collins, N.L. (1998). Adult Attachment Styles, Perceived Social Support and Coping Strategies. Journal of Social and Personal Relationships, 15(3), 323-345.

Oral, T. \& Karababa, A. (2020). Attachment to Parents as a Predictor of Multidimensional Life Satisfaction Among Adolescents. Sakarya University Journal of Education, 10(1), 53-66.

Pant, P. \& Priyanka. (2006). Substance abouse among street children: An empirical study of certain psychological dimensions. Disabilities and Impairments, 20, 28-36.

Piekarski, D.J., Johnson, C.M., Boivin, J.R., Thomas, A.W., Lin, W.C., Delevich, K., Galarce, E. \& Wilbrecht, L.. (2017). Does puberty mark a transition in sensitive periods for plasticity in the associative neocortex? Brain Research, 1654(B), 1. January. 
Rai, R.N. (2008). Perceived Parental Rearing Style and Drug Addiction among Mizo Adolescents. Journal of the Indian Academy of Applied Psychology, 34(1), 69-72.

Ruchkin, V.V. et al. (1998). Interrelations between temperament, character, and parental rearing in maledelinquent adolescents in Northern Russia. Comprehensive Psychiatry, 39(4), 225-230.

Ruchkin, V.V. (2002). Alcohol use in delinquent adolescents from Northern Russia: the role of personality, parental rearing and family history of alcohol abuse. Personality and Individual Differences, 32(7), 1, 1139-1148.

Sato, J.R., Salum, G.A., Gadelha, A., Vieira, G., Zugman, A., Picon, F.A., Pan, P.M., Hoexter, P.M., Anés, M.Q., Moura, L., M., Del'Aquilla, M.A., G., Crossley, N., Junior, E.A., Mcguire, P., Lacerda, A.L.T., Rohde, L.A., Miguel, E.C., Jackowski, A.P. \& Bressan, R.A. (2015). Decreased centrality of subcortical regions during transition to adolescence: A functional connectivity study. NeuroImage, 104, 44-51.

Šavrnochová, M., Almašiová, A., Almáši, M. et al. (2020). Identification of risk groups among primary school pupils in Slovakia and the Czech republic: Creating effective preventive measures in relation to technological addictions. Sociálna práca/Sociální práce. 20(2), 31-49.

Sherman, L.E., Rosenbaum, G.M., Smith, A.R., Botdorf, M.A., Fettich, K., Patrianakos, J.L., McCloskey, M., Steinberg, L.D. \& Chein, J.M. (2019). The interactive effects of peers and alcohol on functional brain connectivity in young adults. NeuroImage, 197, 264-272.

Svoboda, Z., Smolík, A. \& Pérezová, L. (2019) Analýza připravenosti vychovatele na řešení krizových situací jako východisko pro další vzdělávání [Analysis of the educator's readiness to solve crisis situations as a starting point for further education]. In Adult Education 2019 - in the Context of Professional Development and Social Capital. Prague: Czech Andragogical Society, 327- 336.

Tamnes, C.K., Herting, M.M., Goddings, A.-L., Meuwese, R., Blakemore, S.-J., Dahl, R.E., Güroglu, B., Raznahan, B., Sowell, E.R., Crone, E.A. \& Mills, K.L. (2017). Development Truelove-Hill, M., Erus, G., Bashyam, V., Varol, E., Sako, C., Gur, R.C., Gur, R.E., Koutsouleris, N., Zhuo, C., Fan, Y., Wolf, D.H., Satterthwaite, T.D. \& Davatzikos, C. (2020). A Multidimensional Neural Maturation Index Reveals Reproducible Developmental Patterns in Children and Adolescents. Journal of Neuroscience, 40(6), 1265-1275.

Young, K.S., Sandman, C.F. \& Craske, M.G. (2019). Positive and Negative Emotion Regulation in Adolescence: Links to Anxiety and Depression. Brain Sciences, 9(4), 76.

Zhu, F., Cizeron, M., Qiu, Z., Benavides-Piccione, R., Kopanitsa, M.V., Skene, N.G., Koniaris, B., DeFelipe, J., Fransén, E., Komiyama, N.H., \& Grant, SGN (2018). Architektúra synaptómu mozgu. Neuron, 99 (4), 781-799.e10. https://doi.org/10.1016/j.neuron.2018.07.007. 